\title{
Growth and Development of Mentha piperita L. in Nutrient Solution as Affected by Rates of Potassium
}

\author{
Janice Valmorbida ${ }^{1}$ and Carmen Sílvia Fernandes Boaro ${ }^{2}$ \\ ${ }^{1}$ Universidade Estadual Paulista; Faculdade de Ciências Agronômicas; Departamento de Produção Vegetal; C.P. \\ 237; janice@fca.unesp.br; 18.603-970; Botucatu - SP - Brasil. ${ }^{2}$ Universidade Estadual Paulista; Instituto de \\ Biociências; Departamento de Botânica; C.P. 510; 18.618-000; Botucatu - SP - Brasil
}

\begin{abstract}
The influence of potassium on the development of Mentha piperita L. was evaluated in the plants grown in nutritive

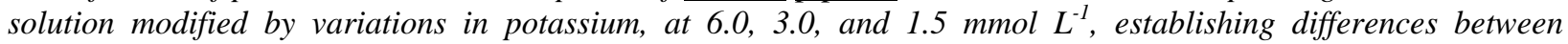
treatments and corresponding, respectively, to the concentration proposed in Hoagland and Arnon's no. 2 solution and reductions by 50\% and 75\%. Until 21 days after transplanting, the concentration used was diluted to 50\% in the three treatments. Evaluations consisted of leaf area, development of the above-ground part, and dry matter of different plant organs. Plants grown with 1.5/3.0 $\mathrm{mmol} \mathrm{L}^{-1} \mathrm{~K}$ showed greater development of the above-ground part. Other variables were not different among plants in the different treatments.
\end{abstract}

Key words: Lamiaceae, mint, leaf area, hydropony, dry matter

\section{INTRODUCTION}

Mentha piperita L., a scent herb of the Lamiaceae family known by the common names of mint, peppermint, spearmint, American mint, brandy mint, lamb mint, or lammint may present branches of different colors varying from dark-green to purple-violet. The leaves are strongly scented due to the presence of essential oils. Mint is widely used for its medicinal properties such as antispasmodic, anti-sickness, anti-helminthic, carminative, stomachic and others (Lorenzi and Matos, 2002). The essential oil is widely used as flavoring and/or additive in foods, toothpaste, and other hygienic products, and in pharmaceutical formulations (Simões and Spitzer, 2000).

Potassium (K) is one of the most important cation macronutrients, since it is demanded in high quantities by the plant cells and plays essential physiological and biochemical functions involving cell osmotic regulation and enzyme activation (Mengel and Kirkby, 1987; Marschner, 1995). Among the important enzymatic reactions activated by $\mathrm{K}$ are P-transferase reactions, involving enzymes such as acetate-kinase, acetylthiokinase, carbonyl-P-synthetase, pyruvatekinase, and also hydrolysis reactions. Potassium enhances the synthesis of Rubisco (ribulose-bis-Pcarboxylase) affecting the rate of $\mathrm{CO}_{2}$ assimilation and is essential for ATPase activity, which is involved in the active mechanism of ion movement through the cell plasma membrane (apoplast/symplast). In case of severe $\mathrm{K}$ deficiency, the accumulation of amine groups (like putrescine) may occur in leaves, resulting in characteristic symptoms (Mengel and Kirkby, 1987; Marschner, 1995). Potassium interacts with almost all essential elements. Increasing $\mathrm{K}$ levels

\footnotetext{
${ }^{*}$ Author for correspondence
} 
reduce $\mathrm{B}, \mathrm{Fe}$ and $\mathrm{Mo}$ uptake, whereas the utilization of $\mathrm{Cu}, \mathrm{Mn}$, and $\mathrm{Zn}$ is increased. Increased $\mathrm{K}$ depresses $\mathrm{Mg}$ in wheat shoots but not in roots, although $\mathrm{K}$ does not affect the rate of $\mathrm{Mg}$ influx (Wilkinson, 1994).

Careful nutrient management is essential to balance high growth in biomass with the production of high quality oil - two essential ingredients for profitable production. Mint has a constant demand for $\mathrm{K}$ during the growing season (Brown et al., 2003).

Considering the various metabolic functions of $\mathrm{K}$ and the lack of information on the effects of this nutrient on Mentha piperita L. yield, this work aimed to evaluate the effect of $\mathrm{K}$ concentrations in nutritive solution in order to obtain a solution that could promote fresh and dry mass increase, thus increasing essential oil yield in the species.

\section{MATERIAL AND METHODS}

The experiment was carried out in a greenhouse from October 28, 2002 through February 24, 2003. During this period, the average maximum and minimum daily temperatures were 29 and $19^{\circ} \mathrm{C}$, respectively.

$M$. piperita $\mathrm{L}$. plantlets showing on average a $13.3-\mathrm{cm}$ shoot-height and $12.9-\mathrm{cm}$ root-length, obtained from three-node rhizomes and rooted for 30 days in the commercial substrate PlantMax ${ }^{\circledR}$, were transferred to hydroponic cultivation, using the nutrient film technique (NFT). All the plants received basic complete Hoagland and Arnon (1950) nutrient solution number 2. Until 21 days after transplanting (DAT), all the plants received this solution diluted to $50 \%$ (half-strength). Treatments consisted of three $\mathrm{K}$ concentrations as follows: full K-treatment, $50 \% \mathrm{~K}$-treatment, and $25 \% \mathrm{~K}$-treatment (Table 1). The nutrient solution $\mathrm{pH}$ was kept around 6.0-6.5 and the solution was replaced whenever electric conductivity showed values below $1.5 \mathrm{mS} \mathrm{cm}^{-1}$. Plants were grown until $21,42,63,84$, and 105 DAT. The experiment was organized as a randomized complete block design with three replications, arranged in split-plots. The main plots consisted of $\mathrm{K}$ concentrations, and subplots represented five harvest periods. Each replication was the average of four plants.

After the harvest, $M$. piperita L. plants were separated into leaf blades, roots, and stalk plus petiole. Leaf blades were evaluated for leaf surface area in a LI 3100 model area meter. All the plant parts were dried in a forced air oven at $60^{\circ} \mathrm{C}$ until constant mass, determined with an analytical balance. The data on shoot length, leaf surface area, and dry matter yield of plant parts and whole plants were submitted to analysis of variance and correlation. Mean comparisons among treatments were made using Duncan test (0.05) according to Banzatto and Kronka (1995).

Table 1 - Treatments to which Mentha piperita L. plants were submitted during their development cycle. Compounds used, concentration in the stock solution $\left(\mathrm{g} \mathrm{L}^{-1}\right)$, treatments $\left(\mathrm{mL} \mathrm{L}^{-1}\right)$.

\begin{tabular}{|c|c|c|c|c|}
\hline \multirow[t]{2}{*}{ Compound } & \multirow{2}{*}{$\begin{array}{c}\text { Concentration of } \\
\text { stock solution } \\
\mathrm{g} \mathrm{L}^{-1}\end{array}$} & \multicolumn{3}{|c|}{$\begin{array}{c}\text { Treatments } \\
\text { Volume of stock solution per liter of final solution }\end{array}$} \\
\hline & & $\begin{array}{c}\text { T1 } \\
\mathbf{m L ~} \mathbf{L}^{-1}\end{array}$ & $\begin{array}{c}\text { T2 } \\
\mathrm{mL} \mathrm{L} \mathrm{L}^{-1}\end{array}$ & $\begin{array}{c}\mathbf{T 3} \\
\mathbf{m L} \mathbf{L}^{-1}\end{array}$ \\
\hline \multicolumn{5}{|l|}{ Macronutrients } \\
\hline $\mathrm{NH}_{4} \mathrm{H}_{2} \mathrm{PO}_{4} \quad(\mathrm{M})$ & 115,00 & 1 & 1 & 1 \\
\hline $\mathrm{Ca}\left(\mathrm{NO}_{3}\right)_{2} \quad(\mathrm{M})$ & 236,16 & 4 & 5,5 & 6,25 \\
\hline $\mathrm{MgSO}_{4} \cdot 7 \mathrm{H}_{2} \mathrm{O} \quad(\mathrm{M})$ & 246,50 & 2 & 2 & 2 \\
\hline $\mathrm{KNO}_{3}$ & 101,10 & 6 & 3 & 1,5 \\
\hline Micronutrients (1) & & 1 & 1 & 1 \\
\hline Solution Fe & & 1 & 1 & 1 \\
\hline Fe-EDTA & 26,10 & & & \\
\hline $\mathrm{FeSO}_{4} \cdot 7 \mathrm{H}_{2} \mathrm{O}$ & 24,90 & & & \\
\hline \multicolumn{5}{|l|}{$\mathrm{K}\left(\mathrm{mmol} \mathrm{L}^{-1}\right)$} \\
\hline Until 21 DAT & & $3,0 \mathrm{mmol} \mathrm{L}^{-1}$ & $1,5 \mathrm{mmol} \mathrm{L}^{-1}$ & $0,75 \mathrm{mmol} \mathrm{L}^{-1}$ \\
\hline After $21 \mathrm{DAT}$ & & $6,0 \mathrm{mmol} \mathrm{L}^{-1}$ & $3,0 \mathrm{mmol} \mathrm{L}^{-1}$ & $1,5 \mathrm{mmol} \mathrm{L}^{-1}$ \\
\hline
\end{tabular}




\section{RESULTS AND DISCUSSION}

There were no significant differences between treatments for variables LA, RDM, LBDM, SPDM, and TPDM. In general, these variables showed a tendency of lower values when submitted to lower potassium, and higher values in plants receiving intermediate $K$ levels (Fig. 1b, d, e, and f and Table 2). Only SL showed a tendency to maintain the highest value at the intermediate $\mathrm{K}$ level and smaller at the lower $\mathrm{K}$ level (Fig. 1c). The results showed that for SL (Fig. 1a), the $0.75 / 1.50 \mathrm{mmol}$ $\mathrm{L}^{-1}$ rate was inferior to the others $(\mathrm{p}<0.05)$. Length of the above-ground part was higher in the treatment with $1.5 / 3.0 \mathrm{mmol} \mathrm{L}^{-1} \mathrm{~K}$. The similar effect of the $\mathrm{K}$ levels in the other analyzed variables (LA, RDM, LBDM, SPDM, TPDM) could be explained by the high correlation coefficients estimated for all the possible combinations $(\mathrm{p}<0.01)$.
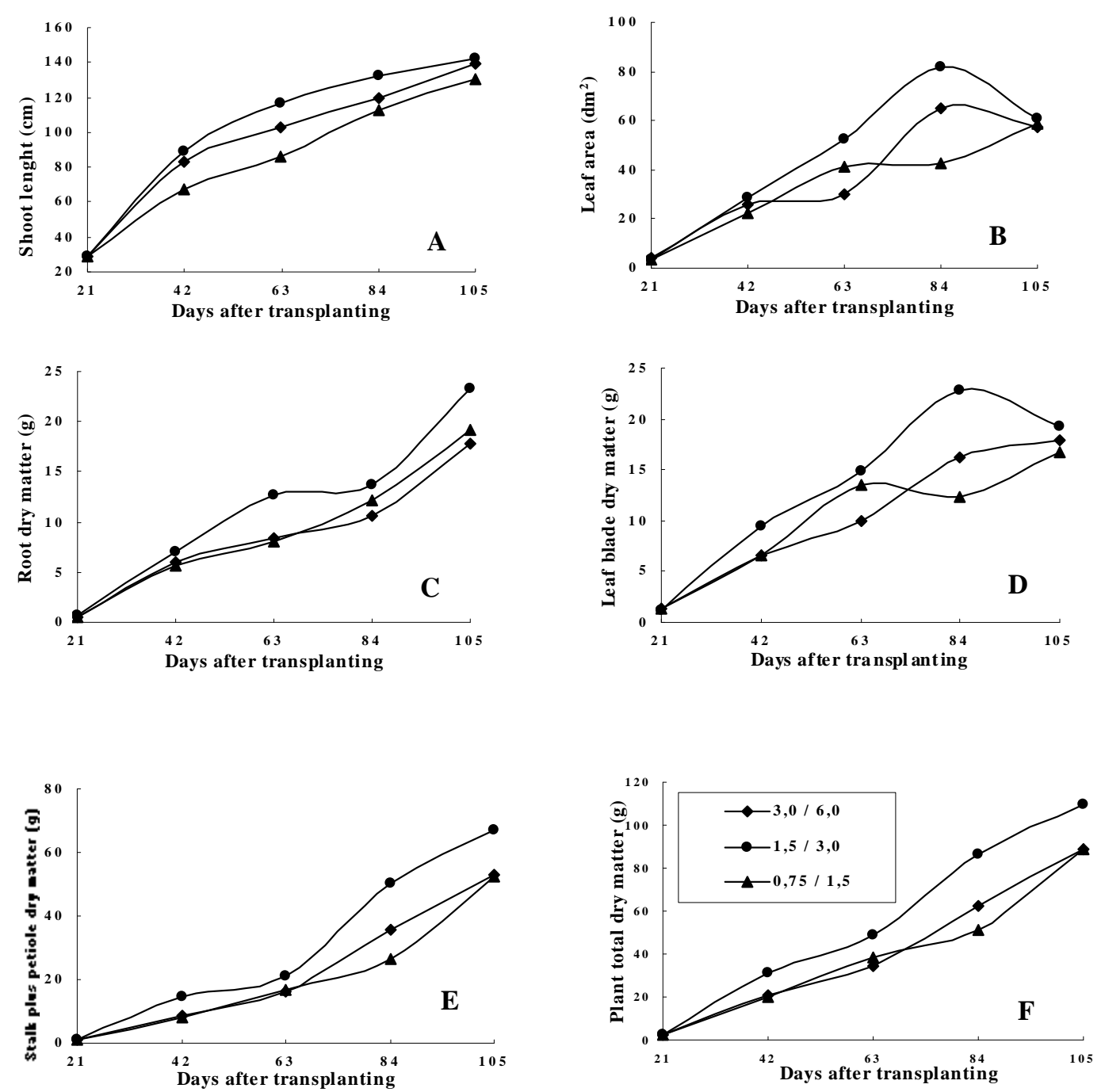

Figure 1 - (A) shoot length $(\mathrm{cm})$; (B) leaf area $\left(\mathrm{dm}^{2}\right)$; $(\mathbf{C})$ root dry matter $(\mathrm{g})$; (D) leaf blade dry matter $(\mathrm{g})$; (E) stalk plus petiole dry matter $(\mathrm{g})$; and $(\mathbf{F})$ plant total dry matter $(\mathrm{g})$ of Mentha piperita L. cultivated in nutrient solution under various $\mathrm{K}$ rates, in harvests from November 2002 through February 2003. Potassium rates refer to K amounts until 1 st harvest/after 1 st harvest in $\mathrm{mmol} \mathrm{L}^{-1}$. 
The results found for SL disagreed from those observed in other species or cultivars. Sinha and Sing (1984) observed a reduction in M. arvensis L. var. piperascens growth under low potassium level due to alterations in nitrogen metabolism. It should be noted that in the present work the lower $\mathrm{K}$ levels were not in the deficient range. Zheljazkov and Margina (1996) evaluated Tundza, Zephir, and Clone no. 1 of M. piperita Huds and cv. Mentolna 18 of $M$. arvensis L var. Piperascens and found an increase in shoot number and length at higher nutrient rates. Santos et al. (2002) cultivated Ocimum basilicum in modified nutrient solutions at strengths of 50, 75, 100 and $125 \%$ and observed higher shoot lengths in the complete nutrient solution.
Plants submitted to the three $\mathrm{K}$ rates presented an increase in shoot length in all the harvesting periods (Table 2). Plants were on average 79.6 and $137.27 \mathrm{~cm}$ tall at 42 and 105 DAT (days after transplanting), respectively 174 and $372 \%$ of growth. Czepak (1998), growing M.arvensis L. under field conditions, observed a maximum plant height of $100 \mathrm{~cm} 120$ DAT, or a little shorter than the ones in the present study, even though the comparison was done between different species and at different temperatures, air humidities, and other conditions. Britten and Basford (1986), sugested day and night optimum growth temperatures for mint as 30 and $18^{\circ} \mathrm{C}$, respectively, comparable to the values prevailing during the present study.

Table 2 - Shoot length (SL), leaf area (LA), root dry matter (RDM), leaf blade dry matter (LBDM), stalk plus petiole dry matter (SPDM), and total plant dry matter (TPDM) of Mentha piperita L. cultivated in nutrient solution under varying $\mathrm{K}$ rates (average of three replications).

\begin{tabular}{|c|c|c|c|c|c|}
\hline \multirow{4}{*}{$\begin{array}{c}\text { Phenological } \\
\text { data }\end{array}$} & \multicolumn{5}{|c|}{ Potassium rates $\left(\mathrm{mmol} \mathrm{L}^{-1}\right)$} \\
\hline & \multicolumn{5}{|c|}{$3.00 / 6.00$} \\
\hline & \multicolumn{5}{|c|}{ Harvest (days after transplanting) } \\
\hline & 1st (21) & 2nd (42) & 3rd (63) & 4th $(84)$ & 5th (105) \\
\hline $\mathrm{SL}(\mathrm{cm})$ & 28.82 & 82.61 & 102.33 & 119.48 & 138.92 \\
\hline $\mathrm{LA}\left(\mathrm{dm}^{2}\right)$ & 4.24 & 26.17 & 30.28 & 64.74 & 57.46 \\
\hline RDM (g) & 0.47 & 5.91 & 8.31 & 10.56 & 17.75 \\
\hline $\operatorname{LBDM}(\mathrm{g})$ & 1.3 & 6.51 & 9.91 & 16.19 & 17.97 \\
\hline $\operatorname{SPDM}(\mathrm{g})$ & 0.87 & 8.77 & 16.1 & 35.51 & 53.18 \\
\hline \multirow[t]{3}{*}{ TPDM (g) } & 2.64 & 21.19 & 34.33 & 62.26 & 88.89 \\
\hline & \multirow{2}{*}{\multicolumn{5}{|c|}{$\begin{array}{c}1.50 / 3.00 \\
\text { Harvest (days after transplanting) }\end{array}$}} \\
\hline & & & & & \\
\hline $\mathrm{SL}(\mathrm{cm})$ & 29.19 & 88.97 & 116.55 & 132.55 & 142.47 \\
\hline $\mathrm{LA}\left(\mathrm{dm}^{2}\right)$ & 3.39 & 28.53 & 52.12 & 82.10 & 60.96 \\
\hline RDM (g) & 0.65 & 6.96 & 12.68 & 13.62 & 23.31 \\
\hline $\operatorname{LBDM}(\mathrm{g})$ & 1.25 & 9.38 & 14.9 & 22.77 & 19.19 \\
\hline $\operatorname{SPDM}(\mathrm{g})$ & 0.87 & 14.72 & 21.28 & 50.1 & 67.04 \\
\hline \multirow[t]{4}{*}{ TPDM $(\mathrm{g})$} & 2.77 & 31.05 & 48.86 & 86.50 & 109.54 \\
\hline & \multicolumn{5}{|c|}{$0.75 / 1.50$} \\
\hline & \multicolumn{5}{|c|}{ Harvest (days after transplanting) } \\
\hline & 1st (21) & 2nd (42) & 3rd (63) & 4th $(84)$ & 5th (105) \\
\hline $\mathrm{SL}(\mathrm{cm})$ & 29.21 & 67.22 & 86.52 & 112.53 & 130.43 \\
\hline $\mathrm{LA}\left(\mathrm{dm}^{2}\right)$ & 3.73 & 22.57 & 40.91 & 42.54 & 58.73 \\
\hline $\mathrm{RDM}(\mathrm{g})$ & 0.44 & 5.71 & 7.99 & 12.17 & 19.18 \\
\hline $\operatorname{LBDM}(\mathrm{g})$ & 1.28 & 6.67 & 13.52 & 12.35 & 16.77 \\
\hline $\operatorname{SPDM}(\mathrm{g})$ & 0.87 & 7.94 & 16.97 & 26.75 & 52.61 \\
\hline TPDM $(\mathrm{g})$ & 2.59 & 20.32 & 38.49 & 51.27 & 88.56 \\
\hline
\end{tabular}

Potassium rates refer to $\mathrm{K}$ amounts until 1st harvest/after 1st harvest. 
The dry matter results obtained from several plant organs (Table 2 and Fig. 1c, d, e and f) differed from those found by other authors, although referring to other plant species cultivated in various nutrient solutions and $\mathrm{K}$ rates. A decrease in root dry matter production was observed by Maia (1998) with $M$. arvensis L. cultivated in the absence of $\mathrm{K}$. The same behavior was noticed by Santos et al. (2002) with Ocimum basilicum cultivated in nutrient solution at 50 and $75 \%$ strength. The available literature refers potassium as an essential nutrient promoting both initial rooting and general root growth. In the present work there was dry matter accumulation in the roots in spite of an adverse effect on leaf area and leaf blade dry matter after 84 days at all $\mathrm{K}$ levels. It was inferred that the lower $\mathrm{K}$ rates used were above the mint deficiency limits.

In general, higher leaf-blade dry matter increases occurred between 21 and 42 DAT (Table 2 and Fig. 1d), a period in which the plant favored leaf production aiming at greater light interception. In all the harvestings, dry matter increased in leaf blades, roots, and shoots plus petioles were observed (Table 2 and Fig. 1d, c, e). There was a 5\% dry matter accumulation between 84 and 105 DAT. Leal (2001) found an average $2.2 \%$ leaf blade dry matter accumulation in the period from 84-98 DAT in plants cultivated in 50\% strength Hoagland's no. 2 complete solution. Sinha and Singh (1982) cultivated M. arvensis L. under K deficiency conditions and observed a sharper decrease in leaf blade dry matter during the 80-100 DAT period. Praszna and Bernath (1993) found a $6.7 \%$ decrease in leaf blade dry matter of $\mathrm{M}$. piperita L. cultivated in nutrient solution without $\mathrm{K}$ as compared to a complete solution treatment. Maia (1998) worked with M. arvensis L. and determined a reduction in leaf blade dry matter when $\mathrm{K}$ was absent from the nutrient solution. The author described necrosis in older leaves starting at 40th DAT, attributed to $\mathrm{K}$ deficiency. In the present work, the lower $\mathrm{K}$ rates in the nutrient solution did not result either in leaf blade dry matter reduction (Table 2) or in any nutritional disorder symptoms, thus disagreeing from the above-mentioned authors.

Comparing stalks plus petioles dry matter results (Table 2 and Fig. 1e) with those of Maia (1998), who found shorter shoots and little side branching for $M$. arvensis cultivated in nutrient solution without $\mathrm{K}$, it could be again suggested that $\mathrm{K}$ did not reach deficiency levels. Despite the fact that higher $\mathrm{K}$ rates did not induce higher stalks plus petioles dry matter, present results are superior to those cited by Leal (2001) cultivating mint in Hoagland and Arnon's no. 2 solution at 50\% strength under similar environmental conditions. Higher total dry matter yield in all the treatments was observed between 84-105 DAT (Fig. 1f). $M$. piperita L. results obtained by Praszna and Bernath (1993) in nutrient solution showed a 4.5\% reduction in plant dry matter in the absence of $\mathrm{K}$, thus confirming the relevance of this nutrient in the plant nutrition, and the idea that in the present work lower $\mathrm{K}$ rates were not enough to induce deficiency. Maia (1998) indicated low mint yield when $\mathrm{K}$ was the limiting nutrient. Shoot, root, and leaf dry matter in guava (Psidium guajava) scions was reduced by $37 \%$ due to the absence of $\mathrm{K}$ (Salvador et al., 1998). Despite of leaf area and leaf blade dry matter reduction after 84 DAT and increases in other traits, especially in plant total dry matter, the medium $\mathrm{K}$ level was ideal for the development, although not significantly different from the higher and lower levels.

With regard to the plant total dry matter (Table 2), $22 \%$ corresponded to roots, $31 \%$ to leaf blades and $47 \%$ to stalks plus petioles. According to Czepak (1998), the higher was the amount of dry matter, the higher was the oil production. The $\mathrm{K}$ level reduction in the nutrient solution did not induce plant deficiency symptoms or dry matter reductions. Both the intermediate $\left(1.5 / 3.0 \mathrm{mmol} \mathrm{L}^{-}\right.$ $\left.{ }^{1}\right)$ and the lower $\left(0.75 / 1.5 \mathrm{mmol} \mathrm{L}^{-1}\right) \mathrm{K}$ rates could be used in M.piperita L. production. However, further evaluations would the required for the oil production and composition under this condition.

\section{ACKNOWLEDGEMENTS}

The authors wish to thank "Coordenação de Aperfeiçoamento de Pessoal de Nível Superior CAPES for financial support.

\section{RESUMO}

A influência do potássio no desenvolvimento de Mentha piperita L. foi avaliada em plantas cultivadas em solução nutritiva modificada pela variação de potássio, com 6.0, 3.0 e $1.5 \mathrm{mmol} \mathrm{L}^{-1}$, 
que estabeleceram as diferenças entre tratamentos e corresponderam, respectivamente, a sua concentração proposta na solução $\mathrm{n}^{\mathrm{o}} 2$ de Hoagland e Arnon e diminuição em 50\% e 75\%. Até os 21 dias após o transplante a concentração utilizada foi diluída em $50 \%$ nos três tratamentos. Avaliou-se área foliar, desenvolvimento da parte aérea e matéria secas dos diferentes órgãos. Plantas cultivadas com $1.5 / 3.0 \mathrm{mmol} \mathrm{L}^{-1} \mathrm{~K}$ apresentaram maior desenvolvimento da parte aérea. Demais variáveis não diferiram entre as plantas dos diferentes tratamentos.

\section{REFERENCES}

Czepak, M.P. (1998), Produção de óleo bruto e mentol cristalizável em oito frequiências de colheita da menta (Mentha arvensis L.). In- Plantas medicinais, aromáticas e condimentares, avanços na pesquisa agronômica. Faculdade de Ciências Agronômicas, Universidade Estadual Paulista, Botucatu, pp. 53-80.

Banzatto, D.A.; Kronka, S. N. (1995), Experimentação Agrícola. $3^{\text {th }}$ ed. Jaboticabal: FUNEP, 247 p.

Britten, E. J. and Basford, K. E. (1986), The effect of temperature on growth, oil yeld and oil quality of Japanese mint. Annals of Botany, Bangkok, 58, 5. 729-736.

Browm, B.; Hart, J. M.; Wescott, M. P.; Christensen, N. W. (2003), The critical role of nutrient management in mint production. Better Crops, 87, 4. 9-11.

Franz, C. (1972), Einfluss der Nãhrstoffe kalium und stickstoff auf die bildung dês ãtherischen Öls von Mentha piperita. Planta Medica, Stuttgart, 22, 2. 160183.

Hoagland, D. R.; Arnon, D. I. (1950), The water: culture method for growing plants without soil. California Agricultural Experiment Station, Berkeley.

Hotyin, A. A. (1956), Viljanyije usyloviji pitanyija na nakoplenyije efirnova maszla u mjati perecskej. Kratkij octset za. 207-212.

Leal, F. P. (2001), Desenvolvimento, produção e composição de óleo essencial da Mentha piperita L., cultivada em solução nutritiva com diferentes níveis de nitrogênio. Dissertação de Mestrado, Botucatu, Faculdade de Ciências Agronômicas, Universidade Estadual Paulista

Lorenzi, H.; Matos, F.J.A. (2002), Plantas medicinais do Brasil: nativas e exóticas. Instituto Plantarum , Nova Odessa.
Maia, N. B. (1998), Efeito da nutrição mineral na qualidade do óleo essencial da menta (Mentha arvensis L.) cultivada em solução nutritiva. In Plantas medicinais, aromáticas e condimentares, avanços na pesquisa agronômica., ed. L. C. MING. Faculdade de Ciências Agronômicas, Universidade Estadual Paulista, Botucatu, pp. 81-95.

Marschner, H. (1995), Mineral nutrition of higher plants. $2^{\text {th }}$ ed.. Academic Press, London.

Mengel, K..; Kirkby. E. A. (1987), Principles of plant nutrition. $4^{\text {th }}$ ed. International Potash, Institute Switzerland.

Praszna, L.; Bernath, J. (1993), Correlations between the limited level of nutrition and essential oil production of peppermint. Acta Horticulturae., 344, 278-289.

Salvador, J.O.; Moreira, A., Muraoka, T. (1998), Deficiência nutricional em mudas de goiabeira decorrente da omissão simultânea de dois macronutrientes. Pesq. Agrop. Bras., 33, 10,16231631.

Santos, J. E., Luz, J.M.Q., Haber, L.L., Furlani, P.R., Batista, A.M., Martins, S.T., Silva, A.P.P. (2002), Diferentes concentrações de solução nutritiva para a cultura de alfavaca (Ocimum basilicum) em sistema de cultivo hidropônico. Trabalho apresentado no $42^{\text {th }}$ Congresso Brasileiro de Olericultura, julho 2002, Uberlândia, Brasil.

Simões, C. M. O. and Spitzer, V. (2000), Óleos voláteis. In - Farmacognosia da planta ao medicamento, C. M. O. Simões et al. 2 ed. Universidade Federal do Rio Grande do Sul, Porto Alegre and Universidade Federal de Santa Catarina, Florianópolis, pp. 394-412.

Sinha, N. C.; Singh, J. N. (1984), Studies in the mineral nutrition of japanese mint; Influence of potassium deficiency and seasonal variation on nitrogen metabolism, respiration rate and essential oil content. Plant Soil, 79,1, 9-51.

Sinha, N. C.; Singh, J. N. (1982). Influence of potassium deficiency on phosphorus metabolism, respiration, foliage growth and essential oil content. Plant Soil, 66, 283-290.

Wilkinson, R.E. (1994), Plant: environment interactions. Marcel Dekker, New York.

Zheljazkov, V.; Margina, A. (1996), Effect of increasing doses of fertilizer application on quantitative and qualitative characteres of mint. Acta Horticulturae, 426, 579-592. 